\title{
Method of assay of red cell folate activity and the value of the assay as a test for folate deficiency
}

\author{
A. V. HOFFBRAND ${ }^{1}$, BEVERLEY F. A. NEWCOMBE ${ }^{1}$, AND D. L. MOLLIN ${ }^{1}$ \\ From the Medical Research Council Group for the Investigation of Megaloblastic \\ and Sideroblastic Anaemias and the Department of Haematology, \\ Postgraduate Medical School of London
}

SYNOPSIS A simplified microbiological assay for determining the folate content of red cells is described. As in previously reported methods Lactobacillus casei is used as test organism but two modifications are introduced. First, haemolysis is carried out in water containing $1 \mathrm{~g} . \%$ of ascorbic acid; secondly, haemolysates are not incubated before the assay. Using this assay, recovery of pteroylglutamic acid added in two different concentrations to five different whole blood samples was $97.0 \pm 1.9$ S.E. $\%$ and $106 \cdot 1 \pm 4.7$ S.E. $\%$ respectively. The coefficient of variation of the assay was between $11 \cdot 2$ and $15 \cdot 0 \%$.

Haemolysates were best stored deep frozen, showing no significant loss of $L$. casei activity for three to five months at $-20^{\circ} \mathrm{C}$. On the other hand, non-haemolysed blood samples were best stored at $4^{\circ} \mathrm{C}$. when there was no loss of activity for seven to 10 days.

Experiments confirmed that plasma is necessary for the maximum release of red cell $L$. casei activity, and showed that only small amounts of plasma are necessary; folate- and $\mathrm{B}_{\mathbf{1 2}}$-deficient plasma released slightly lower $L$. casei activities from red cells than did normal plasma.

The red cell folate levels of 40 healthy normal subjects ranged from 160 to $640 \mathrm{~m} \mu \mathrm{g}$. per ml. of packed red cells. One hundred and twenty patients with subnormal serum folate levels due to idiopathic steatorrhoea, nutritional folate deficiency and Crohn's disease, partial gastrectomy, myelosclerosis, and polycythaemia vera were studied. Red cell folate levels were subnormal (range from 7 to $143 \mathrm{~m} \mu \mathrm{g}$. per $\mathrm{ml}$.) in 40 patients with megaloblastic anaemia, the lowest levels occurring in the most anaemic patients. Subnormal red cell folate levels also occurred in $23(29 \%)$ of the 80 nonanaemic patients. There was a good correlation between red cell folate level and severity of folate deficiency assessed by polymorph nuclear lobe counts, and, in the non-anaemic patients bone marrow morphology. It is concluded that, in the absence of $\mathbf{B}_{12}$ deficiency, the red cell folate level is a precise guide to the severity of folate deficiency.

Patients with serum folate levels less than $3.0 \mathrm{~m} \mu \mathrm{g}$. per ml. almost always had megaloblastic anaemia or obvious morphological changes of folate deficiency. In patients with borderline serum folate levels $(3 \cdot 0-5.9 \mathrm{~m} \mu \mathrm{g}$. per $\mathrm{ml}$.) haematological changes varied widely. The degree of change correlated with the red cell folate level in these patients.

The formiminoglutamic acid (Figlu) test was positive (range 20-660 mg. excreted in eight hours) in all 30 patients with megaloblastic anaemia due to folate deficiency tested and also in $17(31 \%)$ of 54 non-anaemic patients who were folate deficient. The amount of Figlu excreted paralleled the red cell folate level in both the anaemic and non-anaemic, folate-deficient patients tested. Figlu excretion, like the red cell folate level, appeared to be a satisfactory index of tissue folate stores.

In 46 patients with pernicious anaemia, the red cell folate levels ranged from 26 to $396 \mathrm{~m} \mu \mathrm{g}$. per $\mathrm{ml}$., $29(63 \%)$ of them having subnormal levels. The ratio of mean red cell to mean serum folate level, 13.0:1, was lower than that of normal subjects. As in folate deficiency the patients with the lowest haemoglobin concentrations had the lowest red cell folate levels. Figlu was positively excreted in $10(59 \%)$ of 17 patients with pernicious anaemia tested, being particularly increased in those with low red cell folate levels. 
Reticulocytes of patients with pernicious anaemia on treatment and with haemolytic anaemiå were shown to have higher folate levels than their corresponding mature cells. It is concluded that reticulocytes in general have relatively high folate levels.

The serum Lactobacillus casei assay is widely used as a diagnostic test for folate deficiency. The serum folate levels of patients with megaloblastic anaemia due to folate deficiency are invariably lower than those of normal subjects (Baker, Herbert, Frank, Pasher, Hutner, Wasserman, and Sobotka, 1959; Herbert, 1961; Waters and Mollin, 1961; Cooper and Lowenstein, 1961). However, subnormal serum folate levels are also found in a wide variety of conditions in the absence of megaloblastic anaemia or of haematological changes typical of folate deficiency (Hansen, 1964; Herbert, 1965; Johns and Bertino, 1965; Mollin and Hoffbrand, 1965). Furthermore, in experimental nutritional folate deficiency in man the serum folate level falls below normal within a week of starting a folate-deficient diet and reaches very low levels in three weeks (Herbert, 1962a). The liver of a normal adult contains approximately $10 \mathrm{mg}$. of $L$. casei active material (Waters, 1963), and, as the daily requirement for folate is in the region of $50 \mu \mathrm{g}$. (Herbert, $1962 \mathrm{~b}$ ), the serum folate concentration falls before there can be significant depletion of body folate stores. The serum $L$. casei assay is therefore an extremely sensitive test of folate deficiency. For this reason, it may be difficult to assess the severity of the folate deficiency by the use of this assay alone.

Folate deficiency has also been investigated by measuring the excretion of formiminoglutamic acid (Figlu) after a loading dose of histidine (Broquist and Luhby, 1959; Luhby, Cooperman, and Teller, 1959; Knowles, Prankerd, and Westall, 1960; Kohn, Mollin, and Rosenbach, 1961; Chanarin and Bennett, 1962) and by measuring the folate level of the red blood cells (Toennies, Frank, and Gallant, 1956; Grossowicz, Aronovitch, Rachmilewitz, Izak, Sadovsky, and Bercovici, 1960; Hansen and Weinfeld, 1962; Cooper and Lowenstein, 1964; Mollin and Hoffbrand, 1965). These are less sensitive tests of folate deficiency than the serum $L$. casei assay. For example, in experimental folate deficiency the excretion of Figlu and the red cell folate level become abnormal many weeks after the serum folate level falls below normal (Herbert, 1962a). As the metabolism of Figlu by the liver depends on a normally functioning folic acid coenzyme (Bakerman, Silverman, and Daft, 1951; Broquist, 1956), a positive test in a folate-deficient patient presumably indicates that folate depletion is sufficiently severe to interfere with the biochemical function of the liver cells. Circulating red cells contain a good deal more folate material than serum. The material does no $\mathbb{B}$ pass out of the red cells (Herbert and Zalusky, 1962 Hansen, 1964) and a fall in level in folate deficiency therefore indicates a fall in the folate content of the developing haemopoietic tissue.

As diagnostic tests, both these methods have thఱ disadvantage that they may give positive results is the absence of folate deficiency in pernicious anaemia. Thus, the red cell (and therefore whole blood) folate level is low in pernicious anaemia. (Hansen and Weinfeld, 1962; Cooper and Lowen-stein, 1963, 1964; Magnus, 1965; Mollin and Hoffbrand, 1965). The urinary excretion of Figlu is frequently raised in patients with severe $B_{12}$ deficiencys (Zalusky, and Herbert 1961; Kohn et al., 1961 Knowles and Prankerd, 1962; Chanarin, Bennett and Berry, 1962). In addition, the Figlu test may bछ positive in patients with liver disease who are nog $\mathrm{B}_{12}$ or folate deficient (Carter, Heller, Schaffner, and Korn, 1961). Providing $B_{12}$ deficiency is exclude $\omega^{\circ}$ by measuring the serum $B_{12}$ level, it seems likely thas the red cell folate assay and perhaps the Figlu tes might be useful for assessing the severity of folate deficiency.

The main purpose of the present study was $t \vec{\varnothing}$ investigate the value of the red cell folate assay an $\bar{\phi}$ secondly of the Figlu test as indices of the severity of folate deficiency by comparing the results of both. these tests with the serum folate levels and haematoc logical findings in patients with a variety of diseases in which folate deficiency is common. In addition the tests were performed on patients with pernicious anaemia to examine in greater detail the disturbances in relations of serum and red cell folate levels and of Figlu excretion known to occur in this disease? Reticulocytes of patients with pernicious anaemis on $B_{12}$ treatment have been shown to have higher folate activities than the mature pre-treatment ref cells (Herbert and Zalusky, 1962; Hansen and Weinfeld, 1962). In the present investigation th\& folate levels of reticulocytes of patients with haemo $-{ }^{\omega}$ lytic anaemias have been measured to see if reticulor cytes in general have high folate levels.

Previous authors have incubated haemolysates i order to obtain maximum red cell $L$. casei activity? This incubation step has been found unnecessar: and a simplified method for the assay of red cel folate activity is described here. Some of the factor? which have previously been found to influence the results obtained have also been investigated. 
RED CELL FOLATE ASSAY

COLLECTION OF SAMPLeS Approximately $10 \mathrm{ml}$. of venous blood was taken without stasis from subjects one to two hours after breakfast using disposable syringes and needles. A minimum of $1 \mathrm{ml}$. was transferred into a sterile tube containing $4.0 \mathrm{mg}$. of dry ethylene-diamine tetra-acetate (Sequestrene). Six ml. of the blood was taken into a sterile container and allowed to clot at room temperature and the serum was used for vitamin $\mathbf{B}_{12}$ and folate assay. The remainder was collected into a sequestrene tube for haematocrit determination and other haematological tests.

METHOD On the same day, $0.5 \mathrm{ml}$. of the whole blood sample for assay was pipetted slowly into $4.5 \mathrm{ml}$. of distilled water containing $1 \mathrm{~g} . \%$ of freshly added ascorbic acid. Attempts to haemolyse blood in the $0.05 \mathrm{M}$ phosphate buffer, $p \mathrm{H} 6 \cdot 2$, used by Toennies, Usdin, and Phillips (1956), failed to give complete haemolysis. Dilution of the blood sample at least 1:4 in water was also found necessary to give complete haemolysis. The resulting haemolysate was stored at $-20^{\circ} \mathrm{C}$. until the day of assay when it was thawed slowly and an aliquot of $0.5 \mathrm{ml}$. was pipetted into $4.5 \mathrm{ml}$. of $0.1 \mathrm{M}$ phosphate buffer of $p \mathrm{H} 6 \cdot 1$ containing $200 \mathrm{mg} . \%$ of ascorbic acid. The proteins were then precipitated by autoclaving at $10 \mathrm{lb}$./sq. in. for two and a half minutes. The remaining stages of the assay are similar to those described for serum (Waters and Mollin, 1961) and a similar standard pteroylglutamic acid (P.G.A.) curve was used. The usual final dilution of whole blood after this procedure was $1: 800$. If the colorimeter reading of the test sample did not correspond with a sensitive part of the standard P.G.A. curve, the assay was repeated at appropriate higher or lower dilution. Proteins were occasionally incompletely precipitated, so 'blank' tubes containing similar quantities of medium and extract but no organism were set up for each blood sample and the colorimeter reading of each uninoculated blank subtracted from the reading of the corresponding inoculated sample. A second estimation was performed from the same haemolysate after a further week's storage at $-20^{\circ} \mathrm{C}$.

The red cell folate level was then calculated from the mean whole blood folate value by subtracting the folate content of the plasma in the sample, and then correcting for the haematocrit reading, using the formula:

R.B.C.folate $=\frac{\text { Whole blood folate-serum folate }\left(1-\frac{\text { P.C.V. }}{100}\right)}{\frac{\text { P.C.V. }}{100}} \mathrm{m \mu g./ml}$.

EFFECTS OF INCUBATION, CONJUGASE, AND PLASMA ON THE RED CELL L. CASEI ACTIVITY Toennies et al. (1956) incubated red cell haemolysates in their own plasma to obtain maximum $L$. casei activity. Other authors (Grossowicz, Mandelbaum-Shavit, Davidoff, and Aronovitch, 1962; Noronha and Aboobaker, 1963) have obtained even higher levels by incubating with folate conjugase. The following experiments suggest that these cteps are unnecessary, if red cell folate levels are measured by the method described above.
Incubation Twenty-four haemolysates were incubated for 90 minutes at $37^{\circ} \mathrm{C}$. The $L$. casei activity did not increase with incubation at $p \mathrm{H} 5 \cdot 1$ (mean rise $0.12 \mathrm{~m} \mu \mathrm{g} . \%$, $\mathrm{p}=0.99$ ), the usual $p \mathrm{H}$ of the haemolysates, nor when the $p \mathrm{H}$ was adjusted to $6 \cdot 2$, the $p \mathrm{H}$ at which Toennies et al. (1956) incubated haemolysates. As already explained, haemolysis in the buffer $(0.05 \mathrm{M}$ phosphate $p \mathrm{H} \mathrm{6.2)}$ used by Toennies et al. (1956) was incomplete. This may partly explain the increased folate levels with incubation found by these workers.

Conjugase Thirteen haemolysates were incubated for 18 hours at $37^{\circ} \mathrm{C}$. with a chicken pancreas conjugase preparation of known activity. There was a mean fall in L. casei activity of $4 \cdot 1 \%$ which was not significant (p $>0.5<0.6$ ).

Plasma Toennies et al. (1956) first demonstrated that plasma is necessary for the full release of red cell $L$. case $i$ activity. Our experiments confirmed their observations and show that plasma from normal and $\mathrm{B}_{12^{-}}$and folatedeficient subjects was approximately equally effective at releasing the $L$. case $i$ activity of the red cells (Table I). In these experiments whole blood samples were first centrifuged, plasma removed, and the red cells were washed three times in cold isotonic saline. Though higher values were obtained when normal plasma was used rather than $B_{12}$ - or folate-deficient plasma, the differences were not significant.

\section{TABLE I}

RED CELL FOLATE LEVELS MEASURED IN PLASMA AND IN SALINE

\begin{tabular}{|c|c|c|c|c|}
\hline \multirow[t]{2}{*}{ Red Cells } & \multicolumn{3}{|l|}{ Plasma } & \multirow{2}{*}{$\begin{array}{l}\text { Saline } \\
(m \mu g . / m l .)\end{array}$} \\
\hline & $\begin{array}{l}\text { Normal } \\
(m \mu g . / m l .)\end{array}$ & $\begin{array}{l}B_{12^{-}} \\
\text {deficient } \\
(m \mu g . / m l .)\end{array}$ & $\begin{array}{l}\text { Folate- } \\
\text { deficient } \\
(m \mu g . / m l .)\end{array}$ & \\
\hline Normal & $\begin{array}{l}320 \\
237 \\
364\end{array}$ & $\begin{array}{l}263 \\
238\end{array}$ & $\begin{array}{l}300 \\
221 \\
354\end{array}$ & $\begin{array}{r}197 \\
95 \\
237\end{array}$ \\
\hline$B_{12}$-deficient & $\begin{array}{l}164 \\
156 \\
287\end{array}$ & $\begin{array}{l}134 \\
119 \\
252\end{array}$ & 148 & $\begin{array}{r}97 \\
154 \\
179\end{array}$ \\
\hline Folate-deficient & $\begin{array}{r}104 \\
77 \\
66\end{array}$ & 85 & $\begin{array}{l}89 \\
68 \\
62\end{array}$ & $\begin{array}{l}76 \\
32 \\
21\end{array}$ \\
\hline
\end{tabular}

As plasma is necessary for the maximum release of folate activity from red cells, it is possible that falsely low erythrocyte folate levels might be obtained in polycythaemia where the proportion of plasma is reduced and falsely high values in anaemia where the proportion of plasma is increased. The haematocrits of seven normal blood samples were artificially varied between 7 and $86 \%$ before haemolysis but no significant differences in the measured red cell folate activities were obtained between these limits.

EFFECT OF DIFFERENT DILUTIONS AT HAEMOLYSIS Three whole blood samples were haemolysed in water containing $1 \mathrm{~g} . \%$ of ascorbic acid at dilutions ranging from $1: 2$ to $1: 100$. No difference in red cell $L$. casei activity was obtained at dilutions of $1: 4$ or greater. At lower dilutions, lower folate levels were obtained. These could be attri- 
buted to incomplete haemolysis, as intact red cells were present after attempted haemolysis at these low dilutions.

ACCURACY OF THE METHOD The following experiments were carried out to determine the accuracy and reproducibility of the method.

Recovery experiments As the exact identity of the folate compounds present in red cells is unknown, recovery experiments were carried out using folic acid. Pteroyl glutamic acid (P.G.A.) was added to five different whole blood samples. The mean recovery was 97.0 $\pm 1.9 \%$ S.E. when $25 \mathrm{~m} \mu \mathrm{g} . / \mathrm{ml}$. was added and 106.1 $\pm 4.7 \%$ S.E. when $50 \mathrm{~m} \mu \mathrm{g} . / \mathrm{ml}$. was added.

Variability of the assay Three experiments were made to test the variability of the method. (1) Thirty-eight haemolysates were assayed in duplicate in the same assay. The combined coefficient of variation was $11.2 \%$. (2) Eighty haemolysates were assayed in duplicate in two successive assays. The combined coefficient of variation was $15.0 \%$. (3) Three haemolysates (mean folate levels $33.3,101 \cdot 7$, and $194.2 \mathrm{~m} \mu \mathrm{g} . / \mathrm{ml}$.) were assayed in each of 12 successive assay batches. The coefficients of variation were $12.4 \%, 14.9 \%$, and $14.4 \%$ respectively.

Storage experiments These were carried out at room temperature, $4^{\circ} \mathrm{C}$, and $-20^{\circ} \mathrm{C}$. using whole blood samples and haemolysates. For whole blood samples the optimum storage temperature was $4^{\circ} \mathrm{C}$. At this temperature there was no significant loss of activity for seven to 10 days (Table II). There was a fall in $L$. casei activity within 24 to 48 hours of whole blood samples kept at room temperature or at $-20^{\circ} \mathrm{C}$. Haemolysates could be kept at $-20^{\circ} \mathrm{C}$. for between three and five months, but at room temperature or $4^{\circ} \mathrm{C}$. showed a significant loss of activity after seven days. Haemolysates made in distilled water

\section{TABLE II}

RESULTS OF EXPERIMENTS TO DETERMINE THE OPTIMUM STORAGE TEMPERATURES TO PRESERVE THE L. Casei ACTIVITY OF WHOLE BLOOD SAMPLES AND HAEMOLYSATES

\begin{tabular}{|c|c|c|c|c|}
\hline Temperature & $\begin{array}{l}\text { No. of } \\
\text { Specimens }\end{array}$ & $\begin{array}{l}\text { Duration } \\
\text { of } \\
\text { Storage }\end{array}$ & $\begin{array}{l}\text { Mean Rise } \\
\text { or Fall }(\%) \\
\text { of L. casei } \\
\text { Activity }\end{array}$ & Significance \\
\hline \multicolumn{5}{|l|}{ Whole blood } \\
\hline \multirow[t]{3}{*}{ Room } & 8 & 24 hours & $-7 \cdot 6$ & - \\
\hline & 4 & 48 hours & $-20 \cdot 1$ & $+(\mathrm{p}<0.02>0.01)$ \\
\hline & 8 & 72 hours & $-33 \cdot 2$ & $+(\mathrm{p}<0.01)$ \\
\hline \multirow[t]{3}{*}{$4^{\circ} \mathrm{C}$} & 10 & 3 days & +5.4 & - \\
\hline & 10 & $7-10$ days & $-1 \cdot 3$ & - \\
\hline & 10 & 4 days & $-13 \cdot 7$ & $+(p>0.02<0.05)$ \\
\hline$-20^{\circ} \mathrm{C}$ & 8 & 4 days & $-50 \cdot 2$ & $+(p<0.01)$ \\
\hline \multicolumn{5}{|l|}{ Haemolysates } \\
\hline \multirow[t]{5}{*}{ Room } & 4 & 1 day & -6.8 & -.. \\
\hline & 4 & 3 days & $-8 \cdot 6$ & - \\
\hline & 4 & 7 days & $-7 \cdot 9$ & - \\
\hline & 4 & 10 days & $-93 \cdot 7$ & $+(p<0.001)$ \\
\hline & 4 & 14 days & $-93 \cdot 7$ & $+(p<0.001)$ \\
\hline \multirow[t]{6}{*}{$-20^{\circ} \mathrm{C}$} & 9 & 3-5 days & $+2 \cdot 7$ & - \\
\hline & 12 & $7-12$ days & $+4 \cdot 2$ & - \\
\hline & 12 & 18-26 days & +5.0 & -- \\
\hline & 23 & 3 months & $-1 \cdot 1$ & - \\
\hline & 5 & 5 months & $+10 \cdot 5$ & -. \\
\hline & 16 & 7 months & $-18 \cdot 0$ & f. $(p<0.001)$ \\
\hline
\end{tabular}

without added ascorbic acid showed a fall in $L$. cas activity within one to three days, even at $-20^{\circ} \mathrm{C}$.

SEPARATION OF RETICULOCYTES This was performed to differential centrifugation of red cells suspended in ois of varying densities by a modification of the method $\frac{00}{0}$ Danon and Marikovsky (1964). The cells were the washed three times in cold $\left(4^{\circ} \mathrm{C}\right.$.) isotonic saline and reconstituted with their own plasma. There was no fall in the $L$. casei activity of the red cells as a result of thes procedures and the washings contained no significant L. case $i$ activity.

\section{OTHER METHODS}

Serum folate levels were determined by the method Waters and Mollin (1961), normal range from 5.9 to $21.0 \mathrm{~m} \mu \mathrm{g} . / \mathrm{ml}$., and serum $B_{12}$ levels by the method of Anderson (1964), normal range from 160 to $925 \mu \mu \mathrm{g}$. per ml. Figlu excretion was measured in an eight-hour urine specimen by the spectrophotometric method of Chanarin and Bennett (1962), after a loading dose of $15 \mathrm{~g}$. al 1-histidine monohydrochloride. The normal range $\vec{B}$ from 0 to $17 \mathrm{mg}$. Chanarin and Bennett expressed the result as total urocanic acid and Figlu but in this paper only the value for Figlu is given. Haematological methode used were those described by Dacie and Lewis (1963\% In addition, the mean polymorphonuclear lobe count of 100 polymorphs (Herbert, 1959) was calculated on stained peripheral blood films.

\section{SUBJECTS STUDIED}

Observations were made on the following groups subjects:-

1 A normal control group made up of 40 health members of the staff of the Postgraduate Medical Schoof including 24 females and 16 males, with an age range from 19 to 42 years with a mean age of 28 years.

2 A hospital control group was made up of 20 patien with Crohn's disease, polycythaemia vera, or following partial gastrectomy who all had normal serum folate and $\mathrm{B}_{12}$ levels.

3 A group of 120 patients with subnormal seru folate levels who suffered from the diseases listed in Table III. Forty had megaloblastic anaemia due to folate deficiency and the remaining 80 were not anaem or if anaemia was present, it was not due to $B_{12}$ or fola deficiency. These 80 patients are subsequently referref

TABLE II I

COMPOSITION OF GROUP OF 120 PATIENTS WITH SUBNORMAL SERUM FOLATE LEVELS

$\begin{array}{lll}\text { Condition } & \text { No. of } & \text { No. with } \\ & \text { Patients } & \text { Megaloblastic } \\ & \text { Studied } & \text { Anaemia }\end{array}$

Nutritional megaloblastic anaemia Idiopathic steatorrhoea

Crohn's disease

Partial gastrectomy

Myelosclerosis

Polycythaemia vera

Total 
to as the 'non-anaemic, folate-deficient' group. The diagnosis of idiopathic steatorrhoea had been established by demonstrating abnormal absorption of fat, xylose, glucose, folic acid, and vitamin $B_{12}$. Biopsies from each case obtained with a Crosby capsule revealed characteristic jejunal mucosal changes. Nineteen patients were considered to have nutritional megaloblastic anaemia; all gave histories of inadequate diets, intestinal absorption was normal, and no other cause for folate deficiency could be found. None of these patients with megaloblastic anaemia or subnormal serum folate levels had serum $B_{12}$ levels in the range found in overt pernicious anaemia (from 0 to $100 \mu \mu \mathrm{g}$. per ml., Anderson, 1964) though five patients with megaloblastic anaemia had subnormal levels (between 100 and $160 \mu \mu \mathrm{g}$. per ml.). All five responded fully to treatment with physiological doses of folic acid, the bone marrow becoming normoblastic. Iron-deficiency anaemia, if present, was corrected before folate studies were carried out.

4 A group of 46 patients with Addisonian pernicious anaemia.

5 A group composed of three patients with chronic acquired autoimmune haemolytic anaemia.

\section{RESULTS}

RED CELL FOLATE LEVELS OF CONTROL SUBJECTS AND OF FOLATE-DEFICIENT PATIENTS The red cell folate levels of the $\mathbf{4 0}$ healthy control subjects ranged from
166 to $640 \mathrm{~m} \mu \mathrm{g}$. per ml. with a mean of $316 \pm 16$ S.E. $\mathrm{m} \mu \mathrm{g}$. per ml. (Fig. 1). These was no significant difference between the levels of the male and female subjects.

The red cell folate levels of the 20 hospital control patients with normal serum folate levels were all within the normal range whereas the 40 patients with megaloblastic anaemia due to folate deficiency all had subnormal red cell folate levels (ranging from 7 to $143 \mathrm{~m} \mu \mathrm{g}$. per $\mathrm{ml}$.). Subnormal levels also occurred in $29 \%$ (23) of the 80 non-anaemic, folatedeficient patients.

RELATION OF SERUM AND RED CELL FOLATE LEVELS IN FOLATE-DEFICIENT PATIENTS In Fig. 2, the serum and red cell folate levels of the 120 patients with subnormal serum folate levels are compared. There was a moderately good correlation between the results of the two tests $(y=177+55.4(\mathrm{x}-3 \cdot 2) ; \mathrm{r}=$ $0.60, p<0.001)$. Of the 54 patients with serum folate levels less than $3.0 \mathrm{~m} \mu \mathrm{g}$. per ml., $91 \%$ (49) had subnormal red cell levels.

However, normal red cell folate levels were frequent in the patients with borderline (3.0-5.9 $\mathrm{m} \mu \mathrm{g}$. per $\mathrm{ml}$.) serum folate levels, occurring in $76 \%$ (50) of them. Moreover, at any given serum

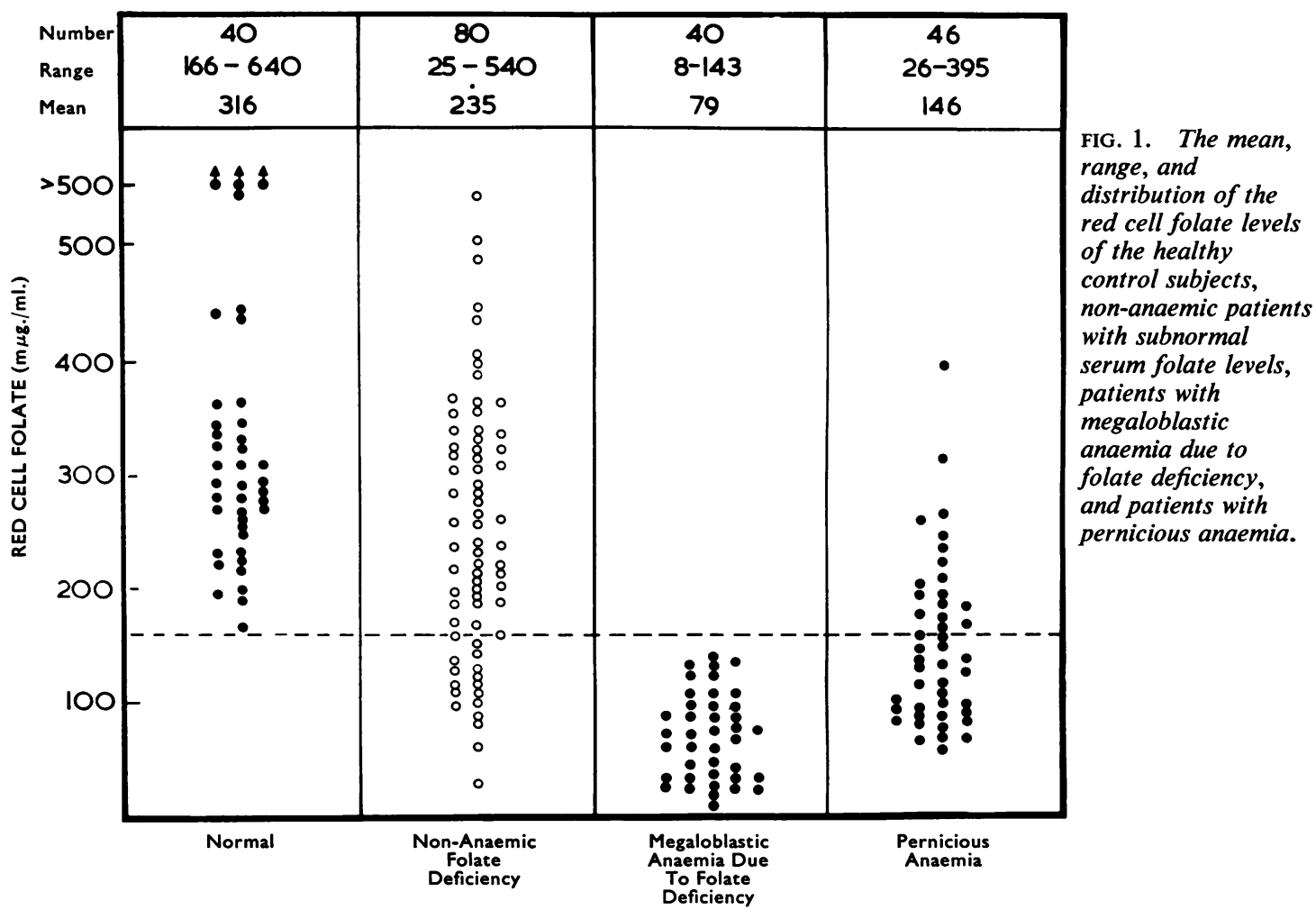




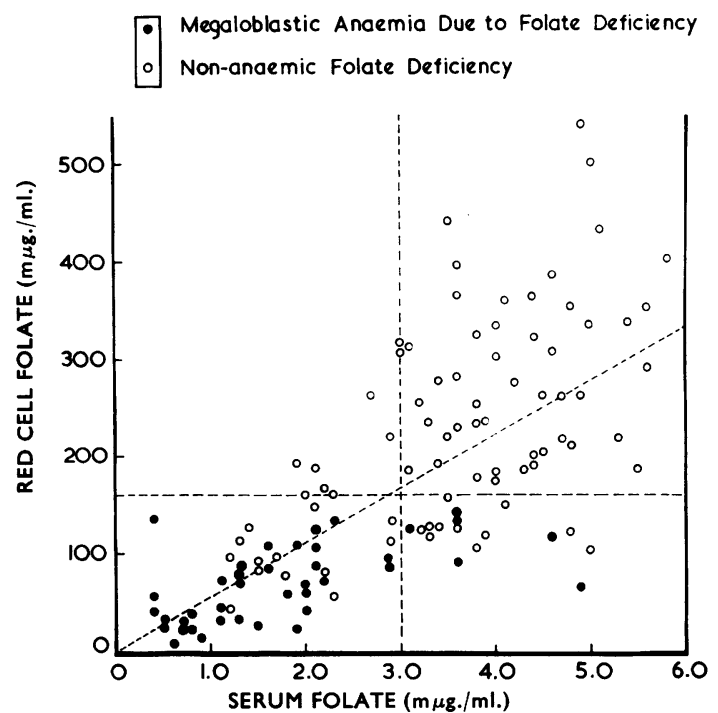

FIG. 2. The relation of red cell to serum folate level in the 120 patients with subnormal serum folate levels. There was a good correlation $(y=177+55.4(x-3 \cdot 2), r=0.68$ $p<0.001)$. The horizontal dotted line represents the lower limit of the normal red cell folate level and the vertical dotted line, the upper limit of the range of serum folate levels $(3.0 \mathrm{~m} \mu \mathrm{g} . / \mathrm{ml}$.) usually found in severe folate deficiency.

folate level in the borderline range, there was a wide variation in red cell folate level; for example, a serum folate level of $3.5 \mathrm{~m} \mu \mathrm{g}$. per ml. was associated with a subnormal red cell folate level in some patients and in one a level less than $100 \mathrm{~m} \mu \mathrm{g}$./ per ml., while in others red cell folate levels were well within the normal range.

Because red cells have a higher folate content than serum, the ratio of red cell to serum folate level is high and in normal subjects the mean ratio was $32 \cdot 6: 1$. The mean ratio was higher than normal in the $\mathbf{4 0}$ patients with megaloblastic anaemia but was highest in the non-anaemic, folate-deficient subjects (Table IV). In folate deficiency, therefore,

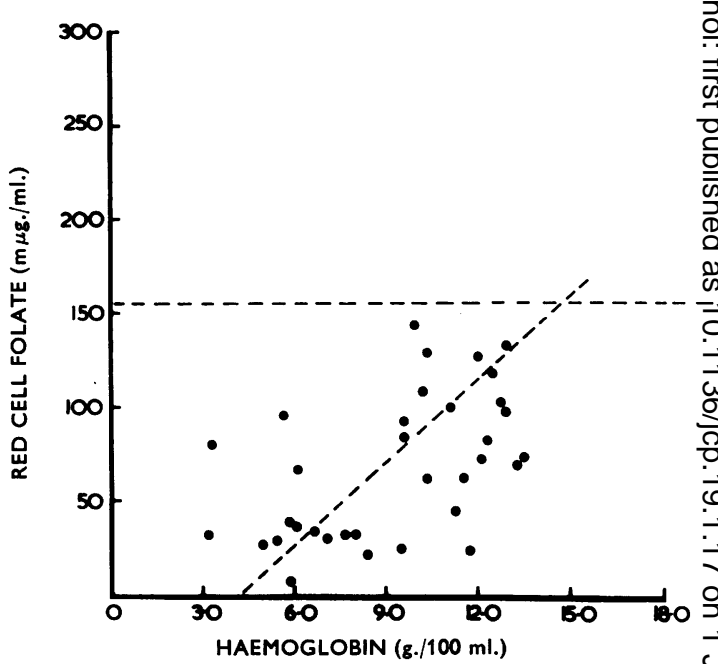

FIG. 3. The relation of the haemoglobin concentration and red cell folate levels of 34 patients with megaloblast anaemia due to folate deficiency. The more anaemin patients had the lower red cell folate levels $(y=73.7+$ $2.18(x-61.5)$ correlation coefficient $0.62 p>0.05$ $<0.02)$. The horizontal dotted line represents the lowe limit of the range of red cell folate level in normal subjects. the mean fall in serum folate level is proportionatel greater than the mean fall in red cell folate leveb particularly before anaemia develops.

COMPARISON OF SERUM AND RED CELL FOLATE LEVEL꾜 WITH HAEMATOLOGICAL FINDINGS The comparative value of serum and red cell folate assays as tests fợ. folate deficiency was assessed by comparing the results of these tests with the haemoglobin coñ centrations of the patients with megaloblastio anaemia, with the polymorph nuclear lobe counts of anaemic and non-anaemic patients, and with the bone marrow appearances of a proportion of the non-anaemic patients.

Haemoglobin concentrations Figure 3 compare the red cell folate and haemoglobin concentrations

TABLE IV

THE RANGE AND MEAN SERUM AND RED CELL FOLATE LEVELS OF THE HEALTHY CONTROL SUBJECTS, PATIENTS WITH MEGALOBLASTIC ANAEMIA DUE TO FOLATE DEFICIENCY, PATIENTS WITH SUBNORMAL SERUM FOLATE LEVELS WITHOUT MEGALOBLASTIC ANAEMIA, AND PATIENTS WITH

\begin{tabular}{|c|c|c|c|c|c|c|}
\hline \multirow{3}{*}{ Condition } & \multicolumn{3}{|c|}{ PERNICIOUS ANAEMIA } & \multirow{2}{*}{\multicolumn{2}{|c|}{$\begin{array}{l}\text { Red Cell Folate Level } \\
(m \mu g . \text { per } m l .)\end{array}$}} & \multirow{3}{*}{$\begin{array}{l}\text { Ratio of Mean Red } \\
\text { Cell Folate Level to } \\
\text { Mean Serum Folate } \\
\text { Level }\end{array}$} \\
\hline & \multirow{2}{*}{$\begin{array}{l}\text { No. of } \\
\text { Subjects } \\
\text { Studied }\end{array}$} & \multicolumn{2}{|c|}{$\begin{array}{l}\text { Serum Folate Level } \\
(m \mu g . \text { per } m l .)\end{array}$} & & & \\
\hline & & Range & Mean & Range & Mean & \\
\hline $\begin{array}{l}\text { Normal control subjects } \\
\text { Megaloblastic anaemia due to folate deficiency } \\
\text { Pernicious anaemia } \\
\text { Non-anaemic folate deficiency }\end{array}$ & $\begin{array}{l}40 \\
40 \\
46 \\
80\end{array}$ & $\begin{array}{l}6 \cdot 0-18 \cdot 6 \\
0 \cdot 4-4 \cdot 9 \\
1 \cdot 6-43 \cdot 5 \\
1 \cdot 2-5 \cdot 8\end{array}$ & $\begin{array}{r}9 \cdot 7 \\
1 \cdot 7 \\
11 \cdot 2 \\
3 \cdot 7\end{array}$ & $\begin{array}{r}166-640 \\
8-143 \\
26-395 \\
25-540\end{array}$ & $\begin{array}{r}316 \\
79 \\
146 \\
235\end{array}$ & $\begin{array}{l}32 \cdot 6: 1 \\
41 \cdot 5: 1 \\
13 \cdot 0: 1 \\
63 \cdot 6: 1\end{array}$ \\
\hline
\end{tabular}




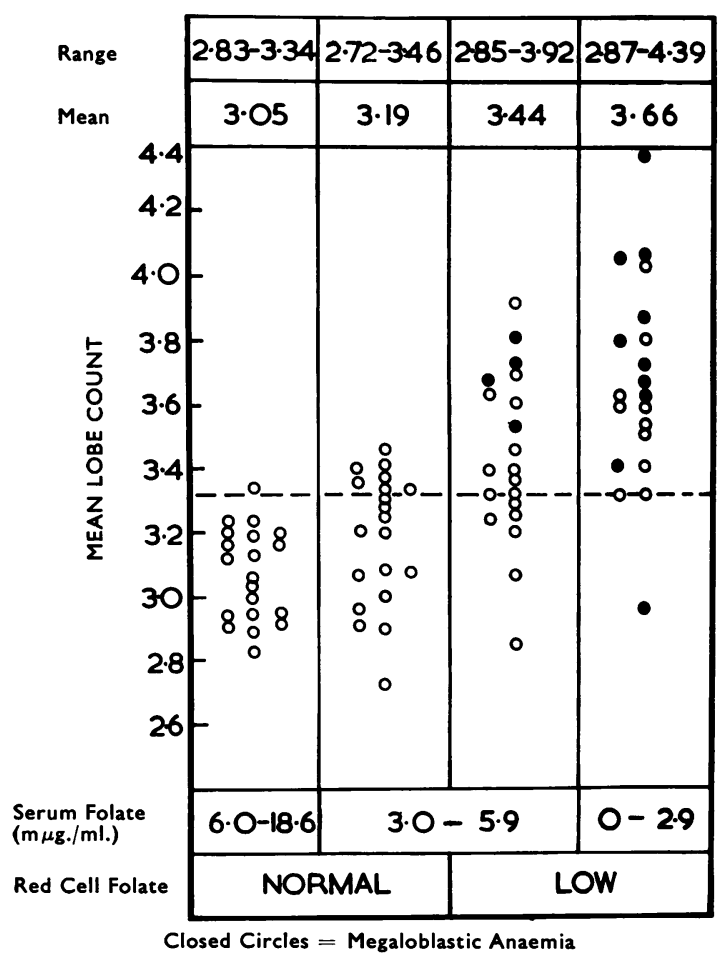

FIG. 4. Comparison of the mean polymorph nuclear lobe counts of patients with normal and low red cell folate levels. The patients are further subdivided on the basis of their serum folate levels. The horizontal dotted line represents the upper limit of the observer's normal range based on films from 20 healthy normal subjects.

of 34 of the 40 patients with megaloblastic anaemia due to folate deficiency. The results of the six patients with myelosclerosis and megaloblastic anaemia are omitted as the anaemia of these six patients was not entirely attributable to folate deficiency. The red cell folate levels were lowest in the most anaemic subjects (correlation coefficient 0.62 ), the patients with haemoglobin concentrations less than $9.0 \mathrm{~g}$. per $100 \mathrm{ml}$. usually having red cell folate levels less than $50 \mathrm{~m} \mu \mathrm{g}$. per $\mathrm{ml}$. and always less than $100 \mathrm{~m} \mu \mathrm{g}$. per $\mathrm{ml}$. In contrast, there was no correlation between the severity of the anaemia of these patients and their serum folate levels.
Mean polymorph nuclear lobe counts The presence of hypersegmented polymorphs in the peripheral blood film is the most easily recognizable and perhaps earliest haematological indication of folate or $B_{12}$ deficiency. In Fig. 4 mean polymorph nuclear lobe counts are compared in patients with normal and subnormal serum and red cell folate levels. The patients with subnormal serum folate levels were made up of 60 of the patients listed in Table III; 40 had borderline (3.0-5.9 m $\mu \mathrm{g}$. per $\mathrm{ml}$.) and 20 had low $(<3.0 \mathrm{~m} \mu \mathrm{g}$. per ml.) serum folate levels. All 20 patients with low serum levels and 20 of the patients with borderline serum levels had subnormal red cell folate concentrations.

Nearly all $(85 \%)$ of the patients with serum folate levels less than $3.0 \mathrm{~m} \mu \mathrm{g}$. per ml. showed raised lobe counts while only $50 \%$ of the patients with borderline serum levels had raised counts (Fig. 4). In the group of patients with borderline serum folate levels, $60 \%(12)$ of those with subnormal red cell levels had raised mean counts whereas only $35 \%$ (7) of those with normal red cell folate levels had raised counts. Moreover, in these seven patients the counts were only just raised above the normal range.

There was a good correlation between the mean lobe counts and the red cell folate levels of the individual patients, the highest counts occurring in the patients with the lowest red cell levels. In contrast, there was a poor correlation between mean lobe count and serum folate level, particularly when the serum level was in the borderline range.

Bone marrow findings The bone-marrow films of 60 non-anaemic patients were classified as normal or as showing megaloblastic change. As none of these patients was anaemic, megaloblastic changes were never severe. For the purpose of this study, the changes present have been divided into mild (occasional intermediate megaloblasts and a few, less than $5 \%$, giant metamyelocytes) and marked (many intermediate megaloblasts and more than $5 \%$ of giant metamyelocytes).

The patients with serum folate levels less than 3.0 $\mathrm{m} \mu \mathrm{g}$. per ml. showed mild or marked megaloblastic changes whereas a large proportion of those with borderline serum folate levels had normoblastic marrows (Table V). In these patients with borderline serum folate levels, megaloblastic changes were

TABLE V

THE BONE-MARROW APPEARANCES OF 60 OF THE 80 PATIENTS WITH SERUM FOLATE LEVELS LESS THAN $6.0 \mathrm{~m} \mu \mathrm{g}$. per $\mathrm{ml}$.

\begin{tabular}{|c|c|c|c|c|c|}
\hline \multirow{2}{*}{$\begin{array}{l}\text { Serum Folate Level } \\
(m \mu g . / m l .)\end{array}$} & \multirow{2}{*}{$\begin{array}{l}\text { Red Cell Folate } \\
\text { Level }(\mathrm{m} \mu \mathrm{g} . / \mathrm{ml} .)\end{array}$} & \multirow{2}{*}{ No. of Cases } & \multicolumn{3}{|c|}{ Bone Marrow Appearance } \\
\hline & & & Normoblastic & Mild Megaloblastic & Marked Megaloblastic \\
\hline $\begin{array}{l}3 \cdot 0-5 \cdot 9 \\
3 \cdot 0-5 \cdot 9 \\
0-2 \cdot 9\end{array}$ & $\begin{array}{l}\text { Normal } \\
\text { Subnormal } \\
\text { Subnormal }\end{array}$ & $\begin{array}{l}30 \\
10 \\
20\end{array}$ & $\begin{array}{l}13(43 \%) \\
0(0) \\
0(0)\end{array}$ & $\begin{array}{c}14(47 \%) \\
3(30 \%) \\
3(15 \%)\end{array}$ & $\begin{array}{r}3(10 \%) \\
7(70 \%) \\
17(85 \%)\end{array}$ \\
\hline
\end{tabular}


always present in those with subnormal red cell folate levels whereas the marrow was normoblastic in $43 \%$ (13) with normal red cell folate levels. Moreover, the changes were marked in $70 \%$ (7) of patients with subnormal red cell levels but in only $10 \%$ (3) of those with normal red cell levels, and, in these three patients, red cell folate levels were only just normal (ranging from 168 to $188 \mathrm{~m} \mu \mathrm{g}$, per ml.).

Therefore there was an excellent correlation between the red cell folate levels of these patients and their haematological evidence of folate deficiency. All the patients with megaloblastic anaemia had subnormal red cell folate levels, the lowest levels occurring in the most anaemic patients; of the non-anaemic patients, those with the lowest levels had the most obvious megaloblastic changes and in both anaemic and non-anaemic patients, those with the lowest red cell levels had the highest mean lobe counts. In contrast, though serum folate levels below 3.0 $\mathrm{m} \mu \mathrm{g}$. per $\mathrm{ml}$. were usually associated with severe morphological changes, there was no correlation between serum folate level and haemoglobin concentration in the anaemic patients. Furthermore in patients with serum folate levels between 3.0 and $5.9 \mathrm{~m} \mu \mathrm{g}$. per $\mathrm{ml}$. there was a wide range of haematological change from severe megaloblastic anaemia to no discernible morphological abnormality. In these patients the severity of haematological change corresponded to the red cell folate level.

FIGLU EXCRETION Figlu tests were carried out in 84 of the 120 patients. They were positive in the 30 patients with megaloblastic anaemia and also in 17 ( $31 \%$ ) of 54 non-anaemic patients. The mean Figlu excretion was greater in the anaemic than in nonanaemic patients with positive tests (Table VI).

There was a good but not perfect correlation between the Figlu excretions and red cell folate levels of these 84 patients (Fig. 5) as $87 \%$ (73) either had positive Figlu tests and subnormal red cell levels or negative Figlu tests and normal red cell folate levels, 11 patients being abnormal by only one or other test.

The incidence of subnormal red cell folate levels and of positive Figlu tests in these patients was, therefore, approximately equal. However, there was

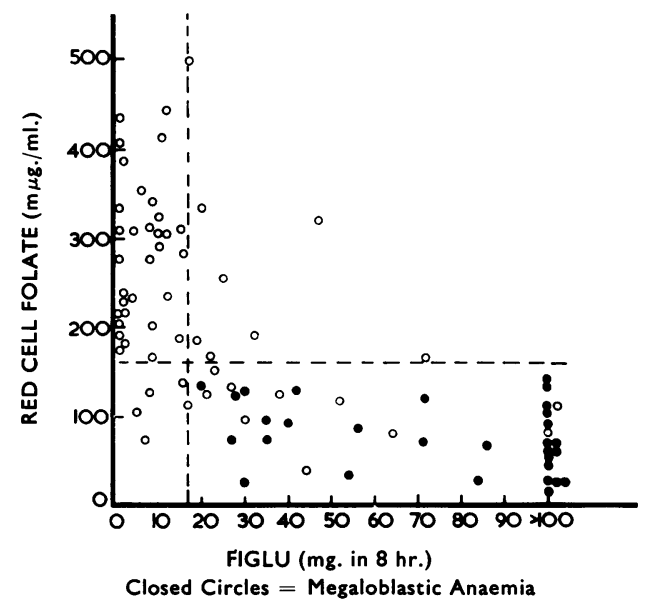

FIG. 5. This compares the red cell folate levels and Figlu excretions of 84 of the 120 patients with subnormal serumw folate levels. The horizontal and vertical dotted line $\overrightarrow{5}$ represent the lower limit of normal red cell folate level and the upper limit of the normal range of Figlu excretion respectively.

only a moderate correlation between the amount of Figlu excreted and the severity of folate deficiencys assessed haematologically in the individual anaemic and non-anaemic patients. The amount of Figlug excreted, therefore, appears to be a somewhat less precise quantitative guide to the severity of folate deficiency in the individual patients than the red cell folate level.

PERNICIOUS ANAEMIA The red cell folate levels of the 46 patients with pernicious anaemia are illus trated in Figure 1. Twenty-nine $(63 \%)$ had sub normal levels. The mean level (146 m $\mu \mathrm{g}$. per ml.) of the 46 patients was greater than the mean of the patients with megaloblastic anaemia due to folate deficiency but was less than the mean level of the normal subjects. In contrast, the mean serum folate level of the pernicous anaemia patients $(11.2 \mathrm{~m} \mu \mathrm{g} N$ per ml.). was significantly higher than normal $(p>0.01<0.02)$.

\section{TABLE VI}

RESULTS OF FIGLU TESTS OF 84 OF THE PATIENTS WITH SUBNORMAL SERUM FOLATE LEVELS AND 17 PATIENTS WITH PERNICIOUS ANAEMIA

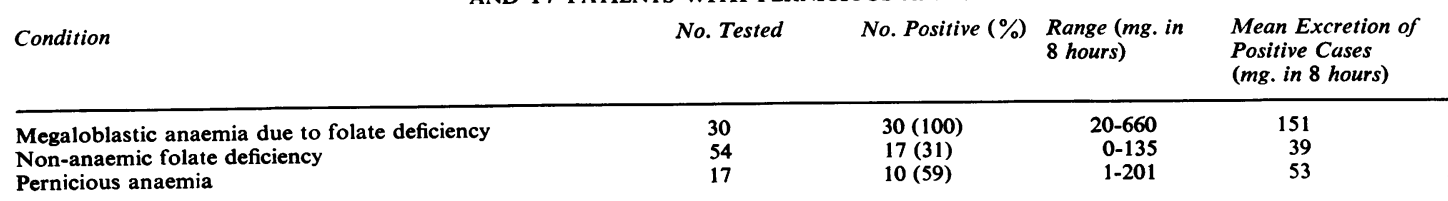




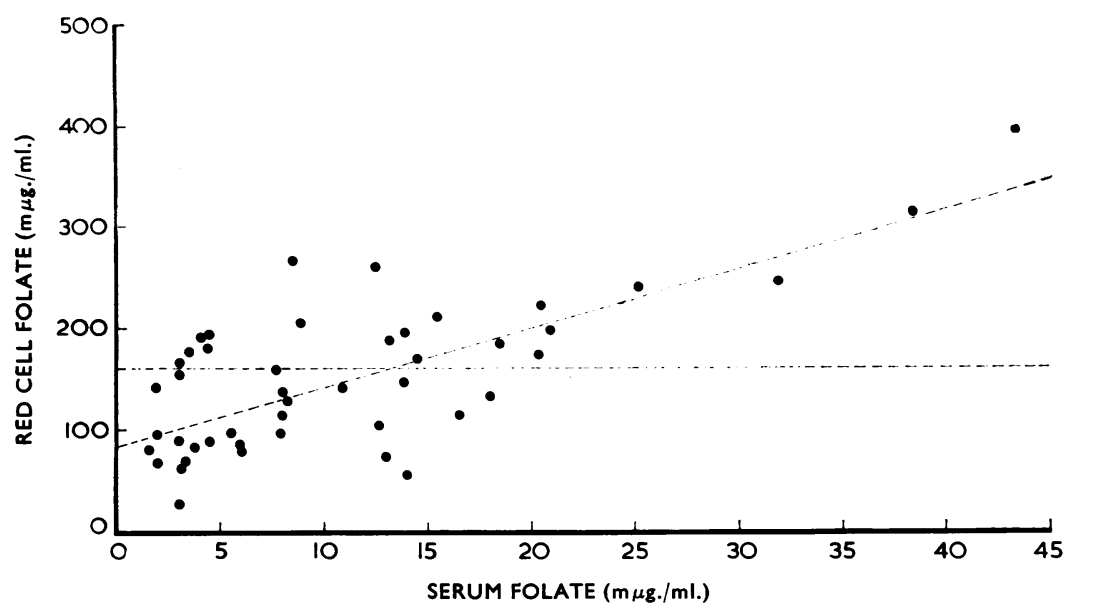

FIG. 6. Comparison of the serum and red cell folate levels in pernicious anaemia. There was a good correlation $(y=146 \cdot 4+5 \cdot 8(x-11 \cdot 1)$ $r=0.74 p<0.05>0.02)$. The horizontal dotted line represents the lower limit of the normal range of red cell folate levels. Thirteen patients $(28 \%)$ had normal serum folate levels and subnormal red cell folate levels.

As in folate-deficient patients, there was a correlation between red cell and serum folate level (Fig. 6) $(\mathrm{y}=146+5.8(\mathrm{x}-11 \cdot 1) \mathrm{r}=0.74 \mathrm{p}<0.05$ $>0.02)$ but the ratio of mean red cell to mean serum folate level in pernicious anaemia (13.0:1) was lower than that of normal subjects (Table IV), subnormal red cell folate levels occurring in 13 patients with normal serum levels (Fig. 6).

As in folate deficiency, the most anaemic patients had the lowest red cell folate levels: $r=0.63$ (Fig. 7). However, comparison of Figs. 3 and 7 shows that at any given haemoglobin concentration, the red cell folate level was lower in folate deficiency than in pernicious anaemia.

Figlu excretion was measured in 17 patients with pernicious anaemia (haemoglobin concentrations

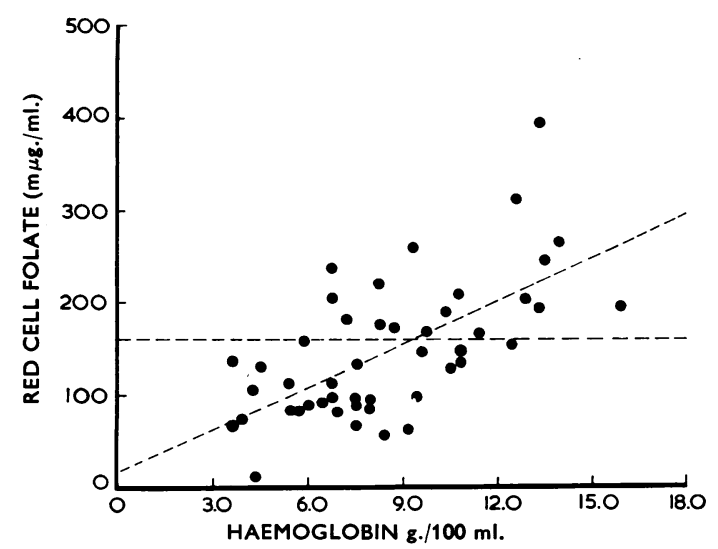

FIG. 7. The relations of red cell folate level to haemoglobin concentration in pernicious anaemia. The most anaemic patients had the lowest red cell folate levels $(y=146 \cdot 4+2 \cdot 3(x-8 \cdot 3) ;$ correlation $0.63, p<0 \cdot 2$ $>0.01)$.

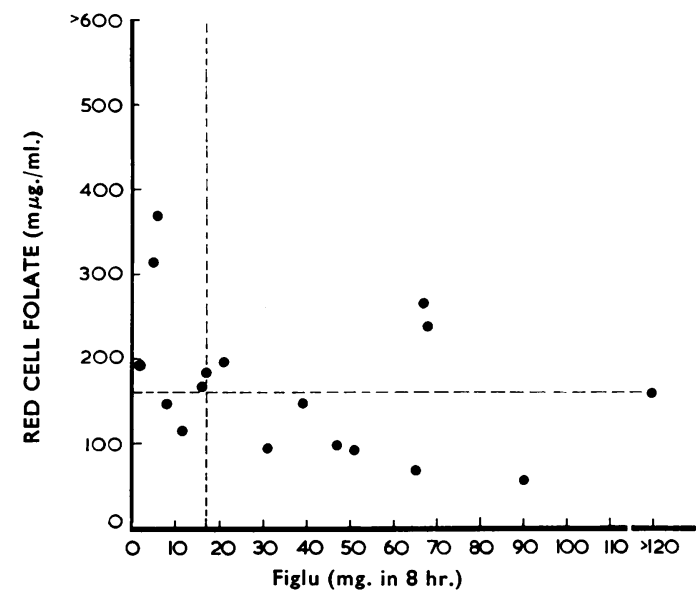

FIG. 8. The relation of red cell folate level and Figlu excretion in pernicious anaemia. The significance of the vertical and horizontal dotted lines is as in Figure 5.

ranging from 5.5 to $13.4 \mathrm{~g}$. per $100 \mathrm{ml}$.) and was positive in $10(59 \%)$ of them (Table V). There was a tendency for Figlu excretion to be increased in the patients with lower red cell folate levels (Fig. 8).

RETICULOCYTES The reticulocytes of three patients with pernicious anaemia receiving vitamin $B_{12}$ therapy and of the three patients with chronic acquired autoimmune haemolytic anaemia were concentrated by differential centrifugation. Table VII compares the $L$. case $i$ activities and reticulocyte concentrations of each of the cell fractions obtained. The cell fractions with the highest reticulocyte counts had the highest folate levels. In pernicious anaemia the differences were large and in case 1 the fraction with $12.4 \%$ reticulocytes had an $L$. casei 
TABLE VII

THE RED CELL FOLATE LEVELS OF THREE PATIENTS WITH PERNICIOUS ANAEMIA DURING TREATMENT WITH VITAMIN $B_{12}$ AND OF THREE PATIENTS WITH ACQUIRED HAEMOLYTIC ANAEMIA ${ }^{1}$

\begin{tabular}{|c|c|c|c|c|c|c|c|c|c|c|}
\hline \multirow[t]{3}{*}{ Diagnosis } & \multirow{3}{*}{$\begin{array}{l}\text { Case } \\
\text { No. }\end{array}$} & \multirow{3}{*}{$\begin{array}{l}\text { Initial } \\
\text { Serum } \\
\text { Folate } \\
\text { Level } \\
(m \mu g . / m l .)\end{array}$} & \multicolumn{2}{|c|}{ Whole Blood } & \multicolumn{6}{|c|}{ Density Fractions of Whole Blood } \\
\hline & & & Red Cell & Reticulo- & $I$ & & $I I$ & & $I I I$ & \\
\hline & & & $(m \mu g . / m l)$. & & $\begin{array}{l}\text { Red Cell } \\
\text { Folate } \\
(m \mu g . / m l .)\end{array}$ & $\begin{array}{l}\text { Reticulo- } \\
\text { cytes }(\%)\end{array}$ & $\begin{array}{l}\text { Red Cell } \\
\text { Folate } \\
(m \mu g . / m l .)\end{array}$ & $\begin{array}{l}\text { Reticulo- } \\
\text { cytes }(\%)\end{array}$ & $\begin{array}{l}\text { Red Cell } \\
\text { Folate } \\
(m \mu g . / m l .)\end{array}$ & $\begin{array}{l}\text { Reticulo- } \\
\text { cytes }(\%)\end{array}$ \\
\hline
\end{tabular}

Pernicious anaemia during therapy with vitamin $B_{12}$

Haemolytic anaemia

$\begin{array}{rrr}14 \cdot 1 & 490 & 5 \cdot 2 \\ 8 \cdot 0 & 280 & 20 \cdot 3 \\ 3 \cdot 0 & 198 & 3 \cdot 7 \\ 1 \cdot 4 & 82 & 8 \cdot 8 \\ 4 \cdot 0 & 204 & 32 \cdot 0 \\ 2 \cdot 1 & 195 & 60 \cdot 0\end{array}$

$\begin{array}{rrrr}960 & 12.4 & 337 & 4 \cdot 2 \\ 527 & 97.0 & 228 & 7 \cdot 8 \\ 272 & 8 \cdot 7 & 137 & 0.6 \\ 95 & 18 \cdot 2 & 100 & 4 \cdot 0 \\ 280 & 61.0 & 264 & 16 \cdot 6 \\ 358 & 67.0 & 201 & 58 \cdot 0\end{array}$

${ }^{1}$ The erythrocytes have been separated into fractions with differing concentrations of reticulocytes and then reconstituted with their own plasma. before assay.

activity (960 m $\mu \mathrm{g}$. per $\mathrm{ml}$.) well above the upper limit of the normal range.

In haemolytic anaemia, the differences were much smaller, and the highest level, $358 \mathrm{~m} \mu \mathrm{g}$. per $\mathrm{ml}$. in fraction I of case 6 , was well within the normal range for mature red cells despite the high reticulocyte concentration $(67 \%)$ of this layer. However, all three patients with haemolytic anaemia had subnormal serum folate levels and, therefore, may have been folate deficient; correction of this deficiency might have increased the folate levels of the fractions with very high reticulocyte concentrations to above the normal range.

\section{DISCUSSION}

METHOD OF RED CELL FOLATE ASSAY The method of red cell folate assay described in this paper is similar to that described by Toennies et al. (1956) but includes two modifications. First, haemolysis is carried out in distilled water containing $1 \mathrm{~g}$. of ascorbic acid per $100 \mathrm{ml}$. Without the protection of added ascorbic acid, the $L$. case $i$ activity of haemolysed blood falls within a few days, presumably due to oxidation of labile folate compounds. Ascorbic acid is therefore necessary if the haemolysates are to be stored, even for a few days. The second modification is that haemolysates were assayed directly without prior incubation in plasma, as this step has been found to have no significant effect on the $L$. casei activities. This finding contrasts with the observation of Toennies et al. (1956) that incubation of haemolysates in their own plasma caused a sevenfold rise in their $L$. casei activities, and it is possible that these large increases noted by Toennies et al. (1956) were due to bacterial synthesis of folate compounds before sterilization and to incomplete haemolysis before incubation. Grossowicz et al. (1962) and Noronha and Aboobaker (1963) report that incubation with conjugase causes greater increase in red cell folate activity than incubation in plasma alone. In our experiments and in those of Hansen (1964) conjugase has not been found to have this effect.

Toennies et al. (1956) also showed that plasma is necessary for the maximum release of the $L$. cased activity of red cells and this observation has been repeatedly confirmed. Cooper and Lowenstein (1964\$ found pernicious anaemia plasma as effective as normal plasma in releasing red cell $L$. casei active material. In the present study, both vitamin $B_{12}$ and folate-deficient plasma were found to release slightly lower red cell $L$. case $i$ activities than normal plasm $\vec{B}$ but the differences were not significant for the number of samples tested. Only small quantities op plasma are necessary for the maximum release of red cell folate activity and therefore results in poly్ㅡㅁ cythaemic patients should not be falsely low, no? those in anaemic subjects falsely high.

The intact red cell appears to be relatively̆ impermeable to folate compounds (Herbert an\& Zalusky, 1962). The optimum storage temperature of whole blood samples is therefore $4^{\circ} \mathrm{C}$., at which temperature haemolysis is slow. At lower tempera tures, haemolysis is more rapid and once haemolysis. occurs there is a rapid loss of $L$. case $i$ activity, unlesf sufficient ascorbic acid is present to protect labile folate compounds from oxidation. Haemolysates on the. other hand, are best stored deep frozefi (at $-20^{\circ} \mathrm{C}$.) with ascorbic acid present. The accurace of the method described is approximately equal te those previously described by Waters and Mollie (1961) for serum and by Cooper and Lowenstein (1964) for red cell $L$. casei assays.

COMPARISON OF THE SERUM AND RED CELL FOLAT? ASSAYS AND THE FIGLU TEST The serum folate assay is a satisfactory test, used in conjunction wit 
the serum $B_{12}$ assay, for investigating patients with megaloblastic anaemia. Used without knowledge of the haematological status of the patient, it provides only a rough guide to the severity of folate deficiency. The results here show that in idiopathic steatorrhoea, nutritional megaloblastic anaemia, Crohn's disease, myelosclerosis, polycythaemia, and after partial gastrectomy, serum folate levels below $3.0 \mathrm{~m} \mu \mathrm{g}$. per $\mathrm{ml}$. usually indicated severe folate deficiency. The results of other workers (Herbert, Baker, Frank, Pasher, Sobotka, and Wasserman, 1960; Waters and Mollin, 1961; Cooper and Lowenstein, 1961) are essentially similar. The interpretation of borderline serum folate levels was more difficult as they occurred not only in patients with severe deficiency, even megaloblastic anaemia, but also in patients with little or no morphological evidence of deficiency.

On the other hand, providing $B_{12}$ deficiency had been excluded, the results showed that the red cell folate level was an accurate quantitative guide to the severity of the deficiency whatever the serum level. Patients with subnormal red cell folate levels either had megaloblastic anaemia or, in the absence of overt anaemia, they had obvious changes in the peripheral film and/or bone marrow, whereas those with normal red cell folate levels did not have megaloblastic anaemia and morphological changes were absent or mild.

Moreover, the red cell folate level paralleled Figlu excretion and, as Figlu metabolism depends on the folate content of the liver cells, the red cell folate level must, like Figlu excretion, be an indirect index of the liver folate concentration. In the absence of $B_{12}$ deficiency, therefore, a subnormal red cell folate level indicates severe depletion of the folate content of both the haemopoietic cells and of the liver cells and therefore significant reduction in the folate content of the principal sites of folate utilization and folate storage in the body.

Because subnormal red cell folate levels are common in pernicious anaemia, the red cell assay is of less value than the serum assay in the routine investigation of patients with megaloblastic anaemia. Used in conjunction with the serum $B_{12}$ assay, however, it can be employed as a precise method of assessing the severity of folate deficiency in individual patients. This is particularly helpful in patients with borderline serum folate levels. It is also of great potential value in studies of the incidence and severity of folate deficiency in population groups in whom detailed haematological studies cannot be carried out. Izak, Rachmilewitz, Zan, and Grossowicz (1963) have shown the value of the red cell folate assay in the investigation of nutritional folate deficiency while Hansen (1964) considers the red cell folate assay the best biochemical test of folate deficiency in pregnancy.

Providing $\mathrm{B}_{12}$ deficiency has been excluded, patients with subnormal red cell folate levels have significant tissue folate depletion and obviously need folic acid therapy, even in the absence of anaemia. On the other hand, it is uncertain if patients with subnormal serum levels but normal red cell folate levels should be given folic acid therapy routinely, as their deficiency is extremely mild and in many is not accompanied by any other biochemical or haematological evidence of deficiency. Furthermore, in our experience, this mild deficiency does not progress unless it is due to a progressive illness.

In the patients with the six diseases commonly associated with folate deficiency studied, Figlu excretion correlated well with their red cell folate levels. In these diseases, the Figlu test is a satisfactory measure of folate deficiency. In other conditions, however, the Figlu test is less reliable for this purpose. Thus in liver disease (Carter et al., 1961), tuberculosis (Chanarin, 1963; Roberts, Hoffbrand, and Mollin, 1966), and carcinomatosis (Kohn et al., 1961; Kershaw and Girdwood, 1964), positive Figlu tests are found in the presence of normoblastic marrows or marrows showing only trivial changes. Furthermore false 'negative' Figlu tests may be found in patients with megaloblastic anaemia of pregnancy (Chanarin, Rothman, and Watson-Williams, 1963) and of anticonvulsant therapy (Hansen, 1964).

PERNICIOUS ANAEMIA Subnormal red cell folate levels were first reported in pernicious anaemia by Hansen and Weinfeld (1962) and their findings have been confirmed by Cooper and Lowenstein (1963, 1964), Magnus (1965), and Mollin and Hoffbrand (1965). In the present study, the lowest red cell levels have been shown to occur in the most anaemic patients. This provides direct evidence that the severity of anaemia in pernicious anaemia may depend on the amount of folate available to the developing red cells. For a similar degree of anaemia however, the red cell folate levels were lower in folate than in $\mathrm{B}_{12}$-deficient patients.

RETICULOCYTES Reticulocytes of patients with pernicious anaemia on treatment have higher folate activities than the corresponding mature cells (Herbert and Zalusky, 1962; Hansen and Weinfeld, 1962; Cooper and Lowenstein, 1964). In the present study, folate levels of the reticulocytes of patients with haemolytic anaemia were also found to be higher than those of the corresponding mature cells. The difference between the folate levels of reticulocytes after therapy and pretreatment cells in pernicious 
anaemia could be due to correction of selective reduction in intracellular folate content. The differences found between the levels of reticulocytes and mature cells in patients with haemolytic anaemia, though far smaller, suggest that reticulocytes in general have higher folate levels than their corresponding mature cells.

It is a pleasure to acknowledge the help we have had in investigating patients from Dr. C. C. Booth, Dr. J. S. Stewart, Dr. J. D. Hines, Dr. S. Kremenchuzky, and Dr. Juden Reed. We should also like to thank the physicians of the Hammersmith Hospital and Dr. L. Bernstock, St. Helier Hospital, Carshalton; Dr. N. F. Coghill, West Middlesex Hospital, Isleworth; Dr. R. J. Harrison, St. James's Hospital, Balham; Dr. M. W. Hutchings, St. Charles's Hospital, London; Dr. P. D. Roberts, West Middlesex Hospital, Isleworth; Dr. R. Vaughan Jones, St. Peter's Hospital, Chertsey, and Dr. F. Villeneuve, Royal Richmond Hospital, Richmond, for allowing us to study patients under their care.

We are also grateful to Dr. A. H. Waters for helpful discussions, Dr. B. B. Anderson for help with statistical calculations, and Mr. J. Morgan and Miss J. Mercy for some of the microbiological assay determinations. Finally, we are indebted to the World Health Organization for continuing financial support.

\section{REFERENCES}

Anderson, B. B. (1964). J. clin. Path., 17, 14.

Baker, H., Herbert, V., Frank, O., Pasher, I., Hutner, S. H., Wasserman, L. R., and Sobotka, H. (1959). Clin. Chem., 5, 275.

Bakerman, H. A., Silverman, M., and Daft, F. S. (1951). J. biol. Chem., $188,117$.

Broquist, H. P. (1956). J. Amer. chem. Soc, 78, 6205.

_- and Luhby, A. L. (1959). Proc. Soc. exp. Biol. (N. Y.), 100, 349.

Carter, F. C., Heller, P., Schaffner, G., and Korn, R. J. (1961). Arch. intern. Med., 108, 41.

Chanarin, I. (1963). Brit. J. Haemat., 9, 141
-_ and Bennett, M. C. (1962). Brit. med. J., 1, 27.

- - - - , and Berry, V. (1962). J. clin. Path., 15, 269

Rothman, D., and Watson-Williams, E. J. (1963), Lancet, 1068.

Cooper, B. A., and Lowenstein, L. (1961). Canad. med. Ass. J., 85, 987

- - (1963). Clin. Res., 11, 191

- - - - (1964). Blood, 24, 502.

Dacie, J. V., and Lewis, S. M. (1963). Practical Haematology, 3rd ed Churchill, London.

Danon, D., and Marikovsky, Y. (1964). J. Lab. clin. Med., 64, 668.

Grossowicz, N., Aronovitch, J., Rachmilewitz, M., Izak, G., Sadovsk so A., and Bercovici, B. (1960). Brit. J. Haemat., 6, 296.

Mandelbaum-Shavit, F., Davidoff, R., and Aronovitch, J. (1962) $\rightarrow$ Blood, 20, 609.

Hansen, H. A. (1964). On the Diagnosis of Folic Acid Deficiency Almqvist and Wiskell, Stockholm.

- and Weinfeld, A. (1962). Acta med. scand., 172, 427.

Herbert, V. (1959). The Megaloblastic Anaemias. Grune and Stratton New York.

- (1961). J. clin. Invest., 40,81.

- (1962a). Trans. Ass. Amer. Phycns, 75, 307.

(1962b). Arch. intern. Med., 110, 649.

(1965). Ann. Rev. Med., 16, 359.

- Baker, H., Frank, O., Pasher, I., Sobotka, H., and Wasserman L. R. (1960). Blood, 15, 228.

- and Zalusky, R. (1962). J. clin. Invest., 41, 1263.

Izak, G., Rachmilewitz, M., Zan, S., and Grossowicz, N. (1963) Amer. J. clin. Nutr., 13, 369.

Johns, D. G., and Bertino, J. R. (1965). Clin. Pharmacol. Ther., 6 372.

Kershaw, P. W., and Girdwood, R. H. (1964). Scot. med. J., 9, 201. \} ^ { 2 }

Knowles, J. P., and Prankerd, T. A. J. (1962). Clin. Sci., 22, 233.

,-- , and Westall, R. G. (1960). Lancet, 2, 347. Kohn, J., Mollin, D. L., and Rosenbach, L. M. (1961). J. clin. Path.

Luhby, A. L., Cooperman, J. M., and Teller, D. N. (1959). Proc. Soc. exp. Biol., (N.Y.) 101, 350.

Magnus, E. M. (1965). Brit. J. Haemat., 11, 188.

Mollin, D. L., and Hoffbrand, A. V. (1965). In Vitamin $B_{12}$ and Folic Acid (Scand. J. Haemat., Series Haematologica, 3), p. 1 . Munksgaard, Copenhagen.

Noronha, J. M., and Aboobaker, V. S. (1963). Arch. Biochem., $101 \stackrel{\mathbb{Q}}{\mathbb{Q}}$ 445.

Roberts, P. D., Hoffbrand, A. V., and Mollin, D. L. (In preparation) $\overrightarrow{\bar{O}}$ Toennies, G., Frank, H. G., and Gallant, D. L. (1956). Cancers (Philad.), 9, 1053.

- Usdin, E., and Phillips, P. M. (1956). J. biol. Chem., 221, 855

Waters, A. H. (1963). Folic Acid Metabolism in the Megaloblast Anaemias. Ph.D. Thesis, University of London.

- and Mollin, D. L. (1961). J. clin. Path., 14, 335

Zalusky, R., and Herbert, V. (1961). J. clin. Invest., 40, 1091. 